\title{
ICAE aktivoi aikuisia maailmanlaajuisesti
}

\author{
— pääsihteeri Budd Hall haastateltavana ${ }^{1)}$
}

JT: Budd Hall, olet toiminut jo pitkään ICAE:n (International Council for Adult Education) pääsihteerinä. Voisitko kertoa lyhyesti mikä on ICAE ja miten se toimii?

BH: ICAE on perustettu 1972 ja siinä on mukana 92 kansallista ja alueellista aikuiskasvatusjärjestöä. Suomi on ICAE:n jäsen Vapaan sivistystyön yhteisjärjestön kautta.

Meidän toimintamme on organisoitu verkostojen (networks) kautta. Meillä on erityisverkostoja $\mathrm{mm}$. seuraavilla alueilla: naiset ja aikuiskasvatus, työväen sivistystyö, koulutus ja rikollisen oikeusturva, osallistava tutkimus, aikuiskasvatus ja perusterveydenhoito sekä tietysti aikuiskasvatus ja rauha. Viimeksimainitun kohdalla Suomella on keskeinen asema, koska Helena Kekkosen johtama Rauhankasvatusinstituutti on maailmanlaajuisen rauhankasvatusverkoston keskuspaikka, josta toimintaa koordinoidaan, ohjataan ja kehitetään.

Yleisesti voidaan todeta, että

1) Yritämme lisätä yhteistyötä ja yhteyksiä maapallon eri osissa asuvien aikuiskasvattajien kesken sekä

2) Yritämme edistää sellaista ajattelua, että aikuiskasvatus tulisi nähdä yhtenä ongelmien ratkaisun välineenä ja että sillä pitäisi olla suurempi yhteiskunnallinen vaikutusvalta yhteiskuntien kehitykseen. Tämän ajattelun mukaan kysymys ei siis ole vain aikuiskasvatuksesta, vaan aikuiskasvatuksen merkityksestä joidenkin elämälle asetettujen tavoitteiden saavuttamisessa.

3) Me kannatamme ja pyrimme edistämään vapaaehtoisten yhdistysten ja verkostojen luomista ja vahvistamista eri maissa aikuiskasvatuksen alueella.

1) Haastattelu on tehty 14.7 .1988 Leedsissä, Englannissa pidetyn Kansainvälisen aikuiskasvatuksen tutkimusryhmän (International Adult Education Research Group) konferenssin aikana.
JT: ICAE on pitkään ollut kehittämässä myös aikuiskasvatuksen tutkijoiden kansainvälisiä yhteyksiä. Mitä odotat Kellogg-säätiön sponsoroimalta aikuiskasvatuksen tutkijoiden kansainväliseltä yhteistyöltä?

$\mathrm{BH}$ : Meidän mielestämme on selvästi olemassa tarvetta vahvistaa sitä, mitä Kellogg-säätiö nimittää "aikuiskasvatuksen intellektuaaliseksi perustaksi". Me toivomme, että kun tutkijat eri maista kokoontuvat yhteen keskustelemaan tutkimuksistaan ja kehittelemään niitä yhdessä sekä tuottamaan uusia ajatuksia; tämä vahvistaa samalla aikuiskasvatuksen asemaa ja auttaa meitä näkemään, mikä on aikuiskasvatuksen rooli ja yhteydet yhteiskunnan muihin toimintamuotoihin.

JT: Osaatko sanoa jotain siitä, miten Kelloggin sponsoroima yhteistyö tulee tulevaisuudessa kehittymään?

BH: En osaa sanoa siitä vielä juuri mitään, sillä tämän konferenssin tehtävänä on juuri tuottaa sekä visioita, mihin tulisi pyrkiä, että kehitellä keinoja, miten asetettuihin tavoitteisiin tulisi pyrkiä.

JT: Joka tapauksessa on ilmeisesti hyvä, että osallistujalistaa on laajennettu aikaisemmasta.

BH: Olen samaa mieltä. On yhä liian paljon sellaisia ihmisiä, joiden pitäisi olla täällä, mutta jotka eivät vielä ole mukana, tämä on vasta alkua.

JT: Olet ollut henkilökohtaisesti mukana monissa eri maissa toteutetuissa osallistavan tutkimuksen $(P R=$ Participatory Research $)$ projekteissa. Voisitko kertoa, mitkä ovat PR:n keskeisimmät peruspiirteet ja lähtökohdat sekä minkälaisia tuloksia näissä projekteissa on saatu?

BH: Saatat hämmästyä, kun kerron sinulle, että ensimmäinen henkilö, jonka minä tiedän käyttäneen termiä "osallistava tutkimus" (participatory research), oli suomalainen nainen nimeltään MarjaLiisa Swantz. Nykyisin hän työskentelee Helsingin yliopiston kehitysmaainstituutissa. Tuolloin hän työskenteli Tansaniassa ja hän ilmeisesti käytti tuota termiä ensimmäiseksi. Ne ajatukset, joita aloimme tuolloin kehitellä Tansaniassa ovat levinneet ja niitä on kehitelty edelleen monissa eri maissa. Siitä kun aloitimme noin 1972 on siis kulunut jo noin $16-17$ vuotta.

Osallistavan tutkimuksen peruslähtökohtana on, että tutkimusongelma täytyy johtaa niiden ihmisten ongelmista, joiden kanssa on tarkoitus työskennellä. Jos on kysymys työntekijöistä, niin jollakin tapaa täytyy löytää keinot, joilla työntekijät saadaan itse muotoilemaan tutkittavat kysymykset.

Jos kysymys on asuinyhteisöstä, niin kysymysten täytyy nousta asukkaiden omasta keskuudesta. Jos kysymys on pohjoisessa asuvista ihmisistä - saamelaisista niin heidän pitää saada itse muotoilla omat ongelmansa. Jos kysymys on alkoholisteista, niin lähtökohtana pitää olla alkoholistien omat ongelmat. Jos kysymys on naisista, niin heidän tulee itse muotoilla omat ongelmansa. Tämä on aina ensimmäinen lähtökohta osallistavassa tutkimuksessa.

Toinen tärkeä seikka on se, että tutkittavat osallistuvat itse tutkimusprosessiin. Ei ainoastaan subjekteina, vaan myös ihmisinä, jotka voivat auttaa tietojen analysoinnissa. Se on usein vaikeaa. Se ei ole aina edes mahdollista. Tämä periaate ei kuitenkaan tarkoita, että tutkijan pitäisi ottaa aina koko yhteisö huomioon, mutta hänen täytyy kehittää jokin luova menettely, jonka kautta yhteisö voi reflektoida ja antaa palautetta omasta olemuksestaan niiltä osin, kun se on tutkimuksen kannalta tärkeätä.

Kolmanneksi, me lähdemme siitä, että tutkimus pitää nähdä so- 
siaalisen intervention yhtenä osana, eikä vain omana itseisarvonaan. Tutkimus ei saa olla ainakaan vain tietty kirja tai jonkun ministeriön raportti, vaan sillä pitää olla jotakin vaikutusta käytännön toimintaan.

JT: Voisitko kertoa jonkin esimerkin osallistavasta tutkimuksesta ja sen avulla saaduista tuloksista?

BH: Kyllä, kerron yhdestä tällaisesta projektista. Se koski erään työpaikan työntekijöiden ammatillista työturvallisuutta ja terveydenhoitoa. Se tehtiin Montrealissa, Kanadassa, eräässä elintarvikealan tehtaassa, jossa jalostettiin kanatuotteita elintarvikemarkkinoille. Naisilla, jotka työskentelivät tehtaassa oli monenlaisia terveysongelmia, heidän polvensa kipeytyivät, heidän kuukautisensa olivat epäsäännöllisiä. heillä oli runsaasti kurkkukipua ja monia muita vastaavia vaivoja. Ammattiliitto, johon he kuuluivat teki tutkimussopimuksen Montrealin yliopiston kanssa. He pyysivät eri alojen spe- sialisteja työskentelemään kanssaan. Tätä varten muodostettiin komitea, jolle tehtaassa työskentelevät naiset kuvasivat ongelmiaan. Tämän jälkeen kehitettiin erilaisia tieteellisiä instrumentteja mittaamaan työn inhimillisyyttä, työpaikan lämpötilaa ja monia muita asioita. Työntekijät ottivat koko ajan aktiivisesti osaa tutkimukseen. Lopuksi työntekijät ja tutkijat analysoivat yhdessä tutkimusaineistoa ja saatuja tuloksia. Mikä tärkeintä, työntekijät tekivät ehdotuksia, kuinka työskentelyolosuhteita tehtaassa voitaisiin parantaa. Projekti oli siis hyvin käytännöllinen case-tutkimus. Työntekijät todella muuttuivat terveemmiksi, koska työnantaja hyväksyi tehdyt ehdotukset ja näin muutokset voitiin toteuttaa. Näin heidän terveydentilansa parani.

JT: Mitä muuta haluaisit kertoa suomalaisille lukijoille?

$\mathrm{BH}$ : Olen tosiasiassa juuri tulossa Suomeen (BH esitti ICAE:n tervehdyksen 23.-25.8.1988 pidetyssä XII yleisessä kansansivistysko- kouksessa). Kerrottakoon vielä, että kun olin juuri aloittanut työni ICAE:ssa vierailin Ruotsissa 1975. Pohjoismaat eivät olleet vielä liittyneet jäseniksi ICAE:hen, koska ne olivat vielä tuolloin huolissaan suhteistaan UNESCO:oon. Vierailin myös Suomessa 1975. Minut toivotettiin tällöin mitä sydämellisimmin tervetulleeksi. Helena Kekkonen ja monet muut aikuiskasvattajat sanoivat kaikki, että he haluavat liittyä ICAE:hen, he olivat kannattamassa neuvoston toimintaa ja he alkoivat työskennellä yhdessä muiden pohjoismaisten aikuiskasvatusjärjestöjen kanssa, niin että ne kaikki tulisivat mukaan ICAE:n toimintaan. Olen sitä mieltä, että Suomen merkitys oli huomattava sen suhteen, että myös kaikki muut Pohjoismaat liittyivät neuvoston jäseniksi. Tästä syystä minä ja muut neuvoston henkilökuntaan kuuluvat arvostamme suomalaisten työskentelyä neuvoston hyväksi. Minulle Suomi on henkilökohtaisesti kuin toinen kotimaa, koska se on monessa suhteessa samanlainen kuin Kanada. 